\title{
The mediating role of the novelty ecosystem between personality traits, entrepreneurial networks and entrepreneurial ambidexterity among small and medium enterprises
}

\author{
Samuel Mayanja ${ }^{1}$ (D) $\cdot$ Michael Omeke $^{2} \cdot$ Josue Vajeru Tibamwenda $^{1} \cdot$ Henry Mutebi $^{3} \cdot$ Fredrick Mufta $^{1}$
}

Received: 30 March 2020 / Accepted: 25 May 2021 / Published online: 14 June 2021

(C) The Author(s) 2021

\begin{abstract}
This paper examines the mediating effect of the novelty ecosystem in the relationship between personality traits, entrepreneurial networking and entrepreneurial ambidexterity. Three hundred eighty-two SMEs in Kampala, Uganda, were studied to explore the influence of the novelty ecosystem. The results show that novelty ecosystem mediates the relationship between personality traits, entrepreneurial networking and entrepreneurial ambidexterity. This suggests that novelty ecosystem is a conduit through which personality traits and entrepreneurial networking relate to entrepreneurial ambidexterity. Business owners/managers should, therefore, create an enabling environment for employees to interact, learn from others through constructive feedback and tolerate learning through slip-ups and putting in place flexible policies to allow creativity. In effect, business owners/managers should create environments that are conducive to opportunity exploration, tension and exploitation.
\end{abstract}

Keywords Personality traits $\cdot$ Novelty ecosystem $\cdot$ Entrepreneurial networks $\cdot$ Entrepreneurial ambidexterity $\cdot$ SMEs

\section{Introduction}

Globally, small and medium enterprises are faced with the challenge of competitive global environments characterised

Samuel Mayanja

smayanja@cavendish.ac.ug; ssekajjasam@gmail.com

Michael Omeke

omekemichael@gmail.com

Josue Vajeru Tibamwenda

josuevajeru@gmail.com

Henry Mutebi

hmutebi@mubs.ac.ug

Fredrick Mufta

fmufta@ cavendish.ac.ug; fred.mufta@gmail.com

1 Faculty of Business and Management, Cavendish University Uganda, Kampala, Uganda

2 Faculty Arts and Social Sciences, Kyambogo University, Kampala, Uganda

3 Faculty of Economics, Energy and Management Science, Makerere University Business School, Kampala, Uganda by uncertainty, complexity and rapid technological changes, which calls for entrepreneurial exploration and exploitation (Foreby et al., 2016). For entrepreneurs to be able to succeed in a dynamic environment, there is a need to learn how to explore and exploit opportunities. The possibility that individuals can perform both exploration and exploitation tasks creates a number of challenges, such as adoptability, skills sets and managing tension, that need to be addressed (Yeganegi et al., 2019). Opportunity exploitation needs ambidextrous managers who can engage in paradoxical thinking, fulfil multiple roles and manage contradictions and conflicting goals. SME owner-managers need to develop the ability to simultaneously combine existing capabilities and explore new ones. There are several paths that managers can follow in order to carry out activities in an ambidextrous fashion to exploit business opportunities (Luger et al., 2018).

Contextually, Uganda is highly endowed with natural resources in the areas of water transport, minerals, agriculture, energy and tourism. The major contributing sectors to Uganda's economy are agriculture, at $24.2 \%$; industry, at $25.5 \%$; and services, at $50.3 \%$ (Uganda Investment Authority (UIA), 2016). Although Uganda presents enormous opportunities, only a few have been explored and exploited. Attempts have been made by 
entrepreneurs to exploit the available opportunities using their personality traits and entrepreneurial networks. In Uganda, over $50 \%$ of all SMEs close shop before they celebrate their second birthday (Turyahikayo, 2015). Uganda's economy needs entrepreneurs who are ambidextrous to explore and exploit these colossal opportunities.

Conceptually, entrepreneurial ambidexterity refers to a business' ability to be aligned and efficient in its management of today's SME demands while simultaneously being adaptive to changes in the environment (Keller \& Weibler, 2014). An ambidextrous business is one that is capable of both exploring new opportunities and exploiting existing competencies with equal dexterity. Entrepreneurial ambidexterity enables a business to enhance its performance and competitiveness (Carayannis \& Rakhmatullin, 2014). Opportunity exploration research has majorly focused on differences in knowledge (or knowledge asymmetries), which explains why some individuals recognise opportunities, while others do not (Shane \& Venkataraman, 2000). Opportunity exploration abilities may differ among individuals because they have different pieces of information available in their world (Baron \& Ensley, 2006; Hayek, 1945). It is also understood that opportunity exploration and exploitation each require different resources and skills sets (Wang \& Chugh, 2014).

Ambidexterity research has mainly been conducted at the organisational, unit and team levels (Gibson \& Birkinshaw, 2004; Keller \& Weibler, 2014). For instance, environmental dynamism (Sidhu et al., 2004), an organisation's structure and culture (e.g. Andriopoulos \& Lewis, 2009) or slack resources (e.g. Voss et al., 2008) were put forward as antecedents of organisational ambidexterity. Research at the individual level focusing on the personality traits of managers, their engagement in exploration and exploitation activities as learning behaviour is still scarce (Keller \& Weibler, 2014; Lee \& Lee, 2016). Though entrepreneurial ambidexterity capabilities may enhance a firm's performance in the long run, this can only be achieved if it attains incremental and radical novelty ecosystems initiated by the business owner-manager. Consequently, this study introduces the mediating effect of the novelty ecosystem to the existing literature that considers the dynamic world SMEs are operating in. This is mainly because opportunity exploitation in a dynamic environment requires interactions of different personalities with divergent ideas to explore and exploit opportunities. The main purpose of this study, therefore, is to analyse the mediating effect of the novelty ecosystem on the relationship between personality traits, entrepreneurial networks and entrepreneurial ambidexterity founded on complexity leadership system theory.

\section{Literature review}

\section{Theoretical foundation}

This study is investigated through complexity systems leadership theory (CSLT) (Goldstein, Hazy \& Lindhult, 2010; Hazy \& Uhl-Bien, 2015), which assumes that organisations are a controlled system with a combination of inflow and outflow of resources, with leadership that understands social interactions as complex and diverse, and that it itself is a source of adaptability. It is also premised on the assumption that interaction resonance practices and trusting associations across the organisation are not a predation that must prevail as a condition for growth, through emergent interactions among actors. The unfolding series of events as well as alertness arising from employee collaboration tend to stimulate opportunity recognition, trigger tension and prompt opportunity evaluation and, consequently, opportunity exploitation (opportunity"TREE") using the novelty ecosystem (Haynie et al., 2009; Shane \& Venkataraman, 2003). Entrepreneurial ambidexterity among SMEs takes place in a complex environment where an entrepreneur finds it hard to predict the future or to access the needed resources to exploit opportunities using linear thinking. In this study, personality traits, entrepreneurial networks, novelty ecosystem and entrepreneurial ambidexterity constructs are derived from CSLT.

\section{Entrepreneurial ambidexterity}

Entrepreneurial ambidexterity refers to an organisation's ability to be aligned and efficiently identify, explore and exploit opportunities while simultaneously being adaptive to changes in the environment (Keller \& Weibler, 2014). An ambidextrous business is one that is capable of both exploiting existing competencies and exploring new opportunities with equal dexterity (Yap et al., 2017). Entrepreneurial ambidexterity capabilities may enhance incremental and radical innovation for the business to adapt to its internal and external environment so as to remain competitive. Ambidextrous businesses are likely to excel at exploiting existing competencies to enable incremental innovation (Junni et al., 2015). Entrepreneurial ambidexterity was operationalised using opportunity identification, tension, evaluation and exploitation (Mom et al., 2009).

\section{Personality traits}

Personality traits are distinctive characters of a person's thoughts, feelings and actions so as to make the individual different from other persons (Vodă \& Florea, 2019). It is known that personality traits not only differentiate between entrepreneurs and non-entrepreneurs, but they also influence 
the intention to start a business. This is because they imply a high perception of control and feasibility in relation to specific behaviour, which is a powerful predictor of intention (Ozaralli \& Rivenburgh, 2016). Karabulut (2016) argues that when the personality of a person is evaluated, it reflects not only the traits of such an individual but also the traits of their society and all humankind at a certain level. There is no consensus among scholars regarding which personality traits are more influential in entrepreneurial ambidexterity among SMEs. However, this study adopts the tested and validated personality traits (personal initiative, self-efficacy, achievement orientation, autonomy of control and conscientiousness) that have been used in other contexts (Keller \& Weibler, 2014).

\section{Entrepreneurial networks}

Entrepreneurial networks are social relationships between an entrepreneur as an individual and his or her SME (Hoang \& Yi, 2015). Entrepreneurial networks connect entrepreneurs to social resources (social support, information) and create and maintain SME relations for competitiveness (Venkatesh et al., 2017). Although there are many networks an entrepreneur can be connected to, it is not clear which type of entrepreneurial network can provide access to the resources that are vital for the discovery and exploitation of opportunities to advance the success of an entrepreneur (Czernek-Marszałek, 2020). However, it is important to recognise that entrepreneurs need to know the key resources needed and how to mobilise them from entrepreneurial networks without losing focus. Entrepreneurial networks are a crucial aspect in tackling resource dependencies related to different business life cycle stages, decisions to be made and the kind of resources needed (Sullivan \& Ford, 2014). In this study, entrepreneurial networks were adopted using tested and validated structural holes, networking styles, ties and embeddedness (Davidsson $\&$ Honig, 2003; Surie \&Hazy, 2006; Vissa, 2012).

\section{Novelty ecosystem}

The novelty ecosystem is a network of interconnected interactions that are connected to a platform that incorporates both production and the use of participants. It creates appropriate value through employee interactions and feedback (Seidel \& Greve, 2017). It is known that the attractiveness of the novelty ecosystem rests on its ability to evoke and highlight interdependencies among employees and the collectivism in which they operate and to provide a fresh way of thinking about knowledge generation, co-evolution and co-creation of value (Costanza, de Groot \& Braat, 2017). Goldstein et al. (2010) and McMillan (2008) further assert that organisation employees who experience novelty ecosystems have their learning boosted from their interactions. Such learning emerges from accumulated pertinent information about extraordinary internal events and the external environment. This can be possible if they pay attention to success stories, focus mainly on the positive rather than the negative trends in a critical environment and attain adaptable ability to perceive the emergence of novelty practices, processes and routines (Frese \& Gielnik, 2014). The novelty ecosystem was operationalised using unfolding series, interactions, order transformation and emergency dynamism (Goldstein et al., 2010; Kibirango et al., 2017).

\section{Personality trait and entrepreneurial ambidexterity}

Personality traits are distinctive characters of a person's thoughts, feelings and actions that make the individual different form other persons (Vodă \& Florea, 2019). Personality traits not only differentiate entrepreneurs from non-entrepreneurs, but they also influence the behaviour to explore and exploit an opportunity (Ozaralli \& Rivenburgh, 2016). However, it is not clear, when one's personality is evaluated, whether it reflects not only the traits of that individual but also the traits of the society and a group of people at a certain level (Moraes et al., 2018). Although many studies have examined the personality of entrepreneurs versus non-entrepreneurs, few, if any, of these studies have explored which personality types are more likely to explore and exploit opportunities.

Mullins and Forlani (2005) suggest that entrepreneurs pursue opportunities that other people do not because they perceive such opportunities differently. Entrepreneurs tend to view some business situations and opportunities more positively than non-entrepreneurs do. Additionally, using the aggregate psychological trait explanation, we argue that the interaction effects between personality traits and environmental unpredictability on entrepreneurial ambidexterity are more pronounced in a low uncertainty avoidance culture (Keller \& Weibler, 2014). Volery et al. (2015) note that there is a research gap in the area of formation of entrepreneurial ambidexterity among individuals; the idea should be researched among entrepreneurs rather than potential entrepreneurs or students, for that matter. Previous studies used personality traits to predict entrepreneurial ambidexterity which were conducted among students, citizens of a country and established entrepreneurs. Thus, the focus of this study is to explore the relationship between personality traits and entrepreneurial ambidexterity among SMEs in Uganda.

H1: Personality traits are positively associated with entrepreneurial ambidexterity.

\section{Personality traits and novelty ecosystems}

Personality traits like openness to experience, curiosity, creativity, intellect and flexibility are associated with exploration 
activities which require experimenting with new approaches and creating novelty ecosystems (Christensen et al., 2018). Furthermore, exploitation activities need behavioural flexibility to disassociate them from existing work practices and routines (Yap et al., 2017). On the other hand, conscientiousness is related to goal-directed behaviour, which requires predefined goals coupled with existing knowledge, competencies and previous experience, in order to exploit for goal attainment, change the status quo and search for new ways. According to Lindhult and Hazy (2016), personality is the consistent behaviour patterns and intrapersonal processes that originate from within an individual to create interactions with others, which creates new processes and methods of doing work.

While entrepreneurship scholars have tended to depict personal traits of the individual entrepreneurs, other factors like culture, institutions and local networks all play a role in creating the novelty ecosystem. Clearly, some novelty ecosystems are created and managed by certain personality traits, which are ambitious, while others are not (Brown \& Mason, 2017). Although personality traits play a vital role in creating the novelty ecosystem, it is not clear which personality traits are more effective in doing so (Kibirango et al., 2017). This study explores which personality traits influence the creation of the novelty ecosystem among SMEs in a developing economy.

H2: Personality traits are positively associated with the novelty ecosystem

\section{Novelty ecosystem and entrepreneurial ambidexterity}

A novelty ecosystem is a network of interconnected webs connected to a focal business that both incorporates production and uses side participants, as well as creates and appropriates value (Sarango-Lalangui, Santos \& Hormiga, 2018). It is known that the attractiveness of the ecosystem construct rests on its ability to evoke and highlight interdependencies between employees and the collectiveness in which they operate and to provide a fresh way to think about the coevolution and co-creation of value in the process of opportunity exploitation (Costanza et al., 2017). The novelty ecosystem can simultaneously pursue the incremental and disruptive innovation needed to achieve sustainability (Goldstein et al., 2010; Kibrango et al., 2017). However, entrepreneurs of SMEs also find themselves in situations where novelty ecosystems are complex because of the dynamic environments, which sometimes limit their predictive capabilities to explore and exploit opportunities. Entrepreneurs need to employ both creation and prediction logics and become adept at cycling between the two as they introduce new ideas and initiatives.
Continuously alternating between the creation and prediction approaches enables individuals and businesses to effectively create novelty ecosystems and manage change (Yeganegi et al., 2019).

An ambidextrous entrepreneur is expected to engage in knowledge brokerage activities among employees to learn from each other through information sharing and feedback. This improves both exploration and exploitation activities in their entrepreneurial endeavour. Information sharing and interactions among employees help in generating new ideas that accelerate entrepreneurial ambidexterity (Aschenbrücker \& Kretschmer, 2018). This study contributes to the relationship between the novelty ecosystem and entrepreneurial ambidexterity among SMEs in developing countries. We, therefore, hypothesise that:

H3: The novelty ecosystem is positively associated with entrepreneurial ambidexterity.

\section{Entrepreneurial networks and novelty ecosystem}

Entrepreneurial networks are social relationships that exist between an entrepreneur as an individual and his or her SME (Mayanja, Ntayi, Munene, Kagaari \& Balunywa, 2019). It is known that entrepreneurial networks connect entrepreneurs to social resources and create and maintain SME relations that contribute to the novelty ecosystem (Sullivan \& Ford, 2014). Entrepreneurial networks are a crucial factor in tackling resource dependencies associated with different life cycle stages, and they are important because they help SMEs in creating the employee interactions and interdependencies useful in decision-making, as well as providing different kinds of information and support (Strobl \& Peters, 2013).

Strobl and Peters (2013) posit that entrepreneurial network attributes determine the size and composition of networks which an SME will participate in. Researchers like Sullivan and Ford (2014) have recognised that entrepreneurial networks enhance interpersonal relationships as well as trust between employees, resulting in the development of social capital and entrepreneurial ambidexterity within SMEs. Individuals embedded within heterogeneous novelty ecosystems are likely to work together and learn from one another. Mason and Brown (2014) add that the usefulness and suitability of entrepreneurial networks and the novelty ecosystem in providing support and information could be a strategic tool to an entrepreneur who operates in a very constrained competitive environment to improve entrepreneurial ambidexterity. The researchers, therefore, hypothesise that:

H4: Entrepreneurial networks are positively associated with the novelty ecosystem. 


\section{Entrepreneurial networks and entrepreneurial ambidexterity}

Entrepreneurial networks provide knowledge about emerging markets and technologies that come from external environment of the firm's boundaries. Entrepreneurial networks consider organisations as social systems with a purpose and that operate in a wider social structure. Organisations are differentiated by the network characteristics of the social relations they have with the society and other organisations (Shane, 20003). This perspective provides an analytical tool to investigate structural, relational and positional embeddedness, tie strengths and trust (Nahapiet \& Ghoshal, 1998). Entrepreneurial networks can help build entrepreneurial competency in all the entities in the network (Seppanen \& Skates, 2001) through knowledge sharing and transfer. This knowledge and information sharing enables an entrepreneur to explore and exploit opportunities in a dynamic environment.

Perry-Smith and Manucci (2017) posit that new ideas, innovation, creativity and organisational changes are important in exploring and exploiting opportunities. Entrepreneurial networks excel at facilitating exploratory, forward-looking activities that promise rewards of exploiting an opportunity. Closed networks, in contrast, perform best in supporting the refinement and improvement of current knowledge, which is typically associated with immediate and relatively certain rewards (Burt \& Soda, 2017). It is noted that differences in entrepreneurial networks are associated with variable information access, which is useful for exploring and exploiting business opportunities in a dynamic environment.

\section{H5: Entrepreneurial networks are positively associated} with entrepreneurial ambidexterity.

\section{Personality traits, novelty ecosystems and entrepreneurial ambidexterity}

The big five personality traits, such as neuroticism, extraversion, openness to experience, agreeableness and conscientiousness, have been dominant in studying personality in organisations and management literature as they cover a broad scope of human personality. Having a similar pattern of learning behaviour, openness to experience and conscientiousness is aligned with the study of novelty ecosystem and entrepreneurial ambidexterity (Kerr et al., 2018).

The personality traits of managers together with their engagement in exploration and exploitation activities represent learning behaviour (Lee \& Lee, 2016). Keller and Weibler (2014) claim that their study was the first to empirically test the personal characteristics and engagement in exploration and exploitation activities, which provides conceptualisation of ambidexterity at the individual level. In some settings, researchers can study how personality traits correlate with the novelty ecosystem and firm investment. Bhatt and Altinay (2013) argue that support and assistance from trusted networks of family and friends minimise the risks of a small SME venture failing in the early years of operation. Further analysis proved that entrepreneurial networks can be a very cost-effective way of improving entrepreneurial ambidexterity among SMEs.

H6: Novelty ecosystems mediate the relationship between personality traits and entrepreneurial ambidexterity.

\section{Entrepreneurial networks, novelty ecosystem and entrepreneurial ambidexterity}

Strobl and Peters (2013) state that entrepreneurial network attributes determine the size and composition of the network which an SME will participate in. Entrepreneurial networks enhance interpersonal trust between employees thus enhancing their interactions within the novelty ecosystem, which contributes to entrepreneurial ambidexterity within SMEs. Castaño-Martínez et al. (2019) add that the usefulness and suitability of entrepreneurial networks and novelty ecosystems in providing social support, information and learning could be a strategic tool to an entrepreneur who operates in a very constrained competitive environment to improve entrepreneurial ambidexterity.

O'Connor et al. (2018) posit that management control systems can allocate attention and resources to exploration or exploitation in an ambidextrous business unit. A novelty ecosystem arises from managerial incentives and from innovation activities that co-exist efficiently, owing to a form of integration driven by senior managers who communicate shared values and visions. It can demonstrate the importance of a favourable social context based on the support and trust of employees. Sullivan and Ford (2014) observe that personality traits, entrepreneurial networks, novelty ecosystems, exploration and exploitation of opportunities (profitability, market coherence, performance objectives) are fraught with a dilemma. He concluded that business should endeavour to balance the tensions between rationalisation (necessity of routines, performance objectives) and creativity (freedom, flexibility) in the process of managing entrepreneurial ambidexterity. In this study we hypothesise that:

H7: The novelty ecosystem mediates the relationship between entrepreneurial networks and entrepreneurial ambidexterity 


\section{Methodology}

This study adopted a quantitative cross-sectional survey design because it enables the collection of large sums of data from the sample in a given period of time. The study population consisted of 94,144 registered SMEs (trade, services and manufacturing sector) based in Kampala district, Uganda (Uganda Bureau of Statistics [UBOS], 2014). Guided by Krejcie and Morgan (1970)'s sample determination table, we targeted a sample of 382 SMEs. We used the stratified random sampling technique based on the nature of SMEs to determine the kth business (246) based on the list of businesses that were in existence for more than 1 year, had more than five employees and whose capital base was more than US\$10,000. The SMEs were selected following the interval of 246, where the first SME selected was number one and the next one was 247 , followed by 493 , and the rest were selected following that pattern. These are SMEs where the instruments were dropped and answered. The questionnaires were self-administered, and after a period of 2 weeks, the completed instruments were picked up by the research team from the selected SMEs. We chose these SMEs because Kampala is the business hub of Uganda with a high concentration of businesses. The unit of analysis was SMEs, while the unit of inquiry was business owners and managers. In each SME, we purposively targeted a business owner and a manager because they are key in opportunity exploration and exploitation. We used a self-administered questionnaire to collect data. A total of 850 questionnaires were distributed to 425 SMEs in a bid to avoid non-response bias and to ensure tenability of the minimum sample of 382. However, we received valid responses from 285 SMEs. Since the SMEs that responded were below the targeted 382 , we had to determine whether the sample size was adequate for the data analysis. We conducted a power analysis using G*Power 3.1 software (Faul et al., 2007). With type 1 error probabilities set to 0.05 , a sample size of 111 was required to reach abundant statistical power of $80 \%$ for a moderate effect size of 0.309 . Therefore, the sample size of this study was deemed adequate for the results of the statistical method to give robust results when using PLS-SEM (Hair et al., 2017). In addition, normality assumptions of the visual inspection of graphical representations of the data, assessment of descriptive statistics and statistical tests of deviation from normal distribution of this sample were considered. Potential non-response bias was examined by comparing early and late responses for all items using the t-test. The results suggested no significant differences between the early respondents and the late respondents $(\mathrm{p}<0.05)$. A nonresponse bias was not problematic.

\section{Measurement of variables}

This relates to the reduction of a phenomenon into representative measurable factors. The study made reference to the theoretical works of previous scholars to come up with reflective measurement items for the variables. Each global variable was measured basing on the works of other scholars and modified to match the Ugandan context. Also, the study anchored all responses in a six-point Likert scale ranging from "definitely agree" (1) to "definitely disagree" (6).

Personality traits In this study, personality traits were conceptualised as owner-manager characteristic patterns of thought, feeling and behaviour. They were measured based on personal initiative, self-efficacy, achievement orientation, autonomy of control and conscientiousness. These are chosen because they are closely linked to entrepreneurial ambidexterity (Keller \& Weibler, 2014). Nine items are used to measure each attribute (John \& Robins, 1994). The sample item for conscientiousness is "I am a reliable worker", while for the dimension of openness to experience is "I have an active imagination".

Entrepreneurial networks An entrepreneurial network was conceptualised as an association of entrepreneurs organised, formally or informally, with the object of increasing the effectiveness of the members' business activities. It was operationalised by the presence of ties, networking styles, structural holes and embeddedness based on Davidsson and Honig (2003), Surie and Hazy (2006) and Vissa (2012). It measured the relationships between contacts of the responding entrepreneur and resources such as information, money, materials, social support and space.

Novelty ecosystem This is conceptualised as a network of interconnected interactions, connected to a platform that incorporates both production and the use of participants. It creates appropriate value through employee interactions and feedback. It was reflected as a mediating variable. First, unidimensional analysis was applied to this variable by examining the magnitude of unfolding series of events witnessed and how they get known and get selected, the level of conformity or submission and how they are adopted and reinforced through networks. It was also examined as a process which is not led by any one individual but emerges through unfolding series of events at every level of the organisation. This was done by considering interactions between ecosystems, eco-subsystems and their environments (interacting ecosystems). In the same manner, respondents were asked to assess the magnitude of the unfolding series of events witnessed and how they get to be known and selected as well as adopted and reinforced through networks (Goldstein et al., 2010; Kibrango et al., 2017).

Entrepreneurial ambidexterity This was conceptualised as an organisation's ability to be aligned and efficiently identify, explore and exploit opportunities while simultaneously being adaptive to changes in the environment. Entrepreneurial 
ambidexterity was operationalised as a personal attribute that refers to the ability to pursue both exploration and exploitation activities at the same time. Ambidexterity is computed by multiplying the score of both activities. The measures for exploration and exploitation activities are adopted from Mom et al. (2009) and consist of seven items. The activities include "Evaluating diverse options with respect to products/services, processes, or market", and, for exploitation, the activities include "Activities which you carry out as if it were routine".

All questions were anchored in a six-point Likert scale. The item scales ranged from 1 ("definitely agree") to 6 ("definitely disagree"). On this kind of rating scale, the respondents could not choose the moderate value or middle point because they had to choose between one of the two qualifications of the scale (Williams, 2019).

\section{Common methods bias}

The study controlled for common methods bias to avoid the inflation or deflation of observed relationships between constructs so as to eliminate type I and type II errors in our study (Lamoureux et al., 2006). In addition, in order to reduce the effect of anxiety, social desirability and acquiescence, some questions were reverse scored. Item complexity and ambiguity were also reduced, as recommended by Podsakoff et al. (2003). To this effect, the respondents were carefully selected to reduce the possible effect of common method bias (Harrison et al., 1996). Based on adequate sample characteristics, $18.4 \%$ of the respondents were drawn from services, $48 \%$ from trade and $33.5 \%$ from manufacturing. Among the sample respondents, $77.1 \%$ were managers, while $22.9 \%$ were business owners. The SMEs that had existed more than 6-10 years were $34 \%$, indicating adequate informant knowledge. Mitchell et al. (2002) indicate that these respondent attributes are apt to explain entrepreneurial ambidexterity. Further, we carefully constructed items of the study by defining unfamiliar terms; removing vague concepts; keeping questions simple, specific and concise; and avoiding double-barrelled questions (Tourangeau et al., 2000). The study adapted the measures derived from previous refereed scholarly works to suit the study context and used a six-point Likert scale to avoid a middle point and then kept the items simple and without multiple meanings (Podsakoff et al., 2012).

\section{Data collection and management}

Data was screened to check for missing values, out of range values and outliers. In this case, we tested for the extent and pattern of missingness using descriptive statistical analysis (Hair et al., 2010). The study examined whether the data was missing completely at random. Little's MCAR test statistical results were chi-square $=58.325, \mathrm{DF}=58$, and Sig. $=$ 0.463 . Since the MCAR test significance value was greater than $\mathrm{p}<0.05$, it was within acceptable range for remedial action. Furthermore, descriptive results showed that the missing values were $854(1.026 \%)$, implying the missing values were less than $5 \%$ within the replacement region. Consequently, the missing values were replaced using the linear interpolation method (Field, 2009).

Data was then converted into partial least squares using the * CVS command in SPSS so as to import it in SmartPLS software version 3.8.1. This was done to enable the researcher to run the measurement models performed in both exploratory and confirmatory factor analyses using partial least square path modelling by way of PLS mode A so as to assess the reliability and validity of the reflective measurement items for the study variables.

\section{Measurement model validation}

The authors ran the PLS structural equation model to validate the reliability and construct validity. In terms of reliability, we used standardised item loading above 0.708 to indicate the item reliability and Cronbach's alpha coefficient and composite reliability. The results indicate that both alpha and composite reliability had values greater than 0.70 , as recommended by Hair et al. (2010). As shown in Table 2, the study found overall acceptable values of Cronbach's alpha coefficient and composite reliabilities, which range between 0.832 and 0.897 and 0.885 and 0.923 , respectively, as shown in Table 2.

Construct validity was assessed in terms of convergent and discriminant validity. Convergent validity was achieved by considering items with a standardised loading above 0.708 and study variable average variance extracted (AVE) greater than 0.5 . The results in Table 1 indicate that all reflective items have a standardised item loading ranging between 0.847 and 0.909 and all study variables have AVE values ranging from 0.553 to 0.670 . Hence, both conditions for convergent validity were met.

\section{Discriminant validity}

To know whether we are dealing with distinct variables, three criteria were used: (1) Fornell and Larcker (1981), where the square root of average variance extracted (AVE) by each construct should exceed the inter-construct correlation; (2) a heterotrait-monotrait (HTMT) correlation ratio of less than 0.85 was considered, as recommended by Hair $\mathrm{Jr}$ et al. (2017) and Henseler et al. (2016); and (3) cross-loadings, where the items of a particular reflective construct should load higher than on other variables. The results in Table 2 and Figure 1 below show that all the three conditions for discriminant validity were met since the square root of the AVE is significantly larger than any correlations involving the construct, indicating that all constructs share greater variance with their own measures than with other constructs. Besides, all the 
Table 1 Construct reliability and validity

\begin{tabular}{lcccc}
\hline Study constructs & Cronbach's alpha & rho_A & Composite reliability & $\begin{array}{l}\text { Average variance } \\
\text { extracted (AVE) }\end{array}$ \\
\hline Entrepreneurial ambidexterity & 0.832 & 0.847 & 0.879 & 0.553 \\
Entrepreneurial networking & 0.897 & 0.909 & 0.923 & 0.670 \\
Novelty ecosystem & 0.881 & 0.893 & 0.905 & 0.663 \\
Personal traits & 0.837 & 0.847 & 0.885 & 0.610 \\
\hline
\end{tabular}

HTMT values were less than 0.85, and the cross-loading results in Tables 4 and 5 indicate that all the measurement items load more highly on their own latent construct than on other constructs. However, three personality traits were dropped because they would negatively affect the convergent and discriminant validity of the PLS measurement model, as suggested by Hair Jr et al. (2017).

\section{Data analysis and results}

To test for the hypothesised relationships and their significance, regression analysis was performed using PLS-SEM and bootstrapping using 5000 sub-samples at $95 \%$ confidence interval (Hair, Hult, Ringle \& Sarstedt, 2017). This involves constructing PLS-SEM to test for the structural relationships among latent constructs (see Figure 1) to assess the direct mediation and moderation effects following a two-tailed test for the significance of the hypotheses. To achieve significance of the hypotheses, the 5000 sub-sample bootstrapping procedure was used to derive a bootstrap confidence interval with 95\% level of confidence (Chin \& Dibbern, 2010, pp.171193). Also, to determine the variance $\left(\mathrm{R}^{2}\right)$ explained by the independent variable on the dependent variable, first, we determined the collinearity of the exogenous construct of a determined endogenous construct. Hair Jr et al. (2017) suggest that the collinearity (VIF) values should be less than 5 and tolerance levels greater than 0.20 . The above two conditions were met as the VIF values were lower than 5 and the tolerance values were above 0.2 , indicating that there was no bias in the exogenous variables to inflate the endogenous variable. Additionally, Stone-Geisser's test for predictive relevance (Q2) was considered further as a criterion to measure the predictive relevance of the dependent constructs used to estimate the dependent variable. The results indicate that all the paths had a predictive relevance of 0.3 and above.

\section{Results}

\section{Descriptive results}

The nature of the business results shows that $48.1 \%$ of the SMEs were involved in trade, $33.5 \%$ in manufacturing and $18.4 \%$ in service provision. In terms of sex, $59.5 \%$ of the
Table 2 Discriminant validity of the study variables

\begin{tabular}{lllll}
\hline Study constructs & $\begin{array}{l}\text { Entrepreneurial } \\
\text { ambidexterity }\end{array}$ & $\begin{array}{l}\text { Entrepreneurial } \\
\text { networking }\end{array}$ & $\begin{array}{l}\text { Novelty } \\
\text { ecosystem }\end{array}$ & $\begin{array}{l}\text { Personal } \\
\text { traits }\end{array}$ \\
\hline $\begin{array}{l}\text { Fornell-Larcker criterion } \\
\text { Entrepreneurial } \\
\text { ambidexterity }\end{array}$ & 0.743 & & \\
Entrepreneurial networking & 0.353 & 0.819 & 0.814 \\
Novelty ecosystem & 0.397 & 0.756 & 0.370 \\
Personal traits & 0.507 & 0.418 & \\
Heterotrait-monotrait ratio (HTMT) & & & \\
Entrepreneurial ambidexterity & & & \\
Entrepreneurial networking & 0.407 & 0.834 & \\
Novelty ecosystem & 0.463 & 0.505 & \\
Personal traits & 0.614 & & 1.212 \\
Inner VIF values & & & \\
Entrepreneurial ambidexterity & & & 1.212 \\
Entrepreneurial networking & 2.458 & & \\
Novelty ecosystem & 2.351 & 1.222 & & \\
Personal traits & & & \\
\hline
\end{tabular}


Fig. 1 PLS-SEM for the HOCs entrepreneurial ambidexterity

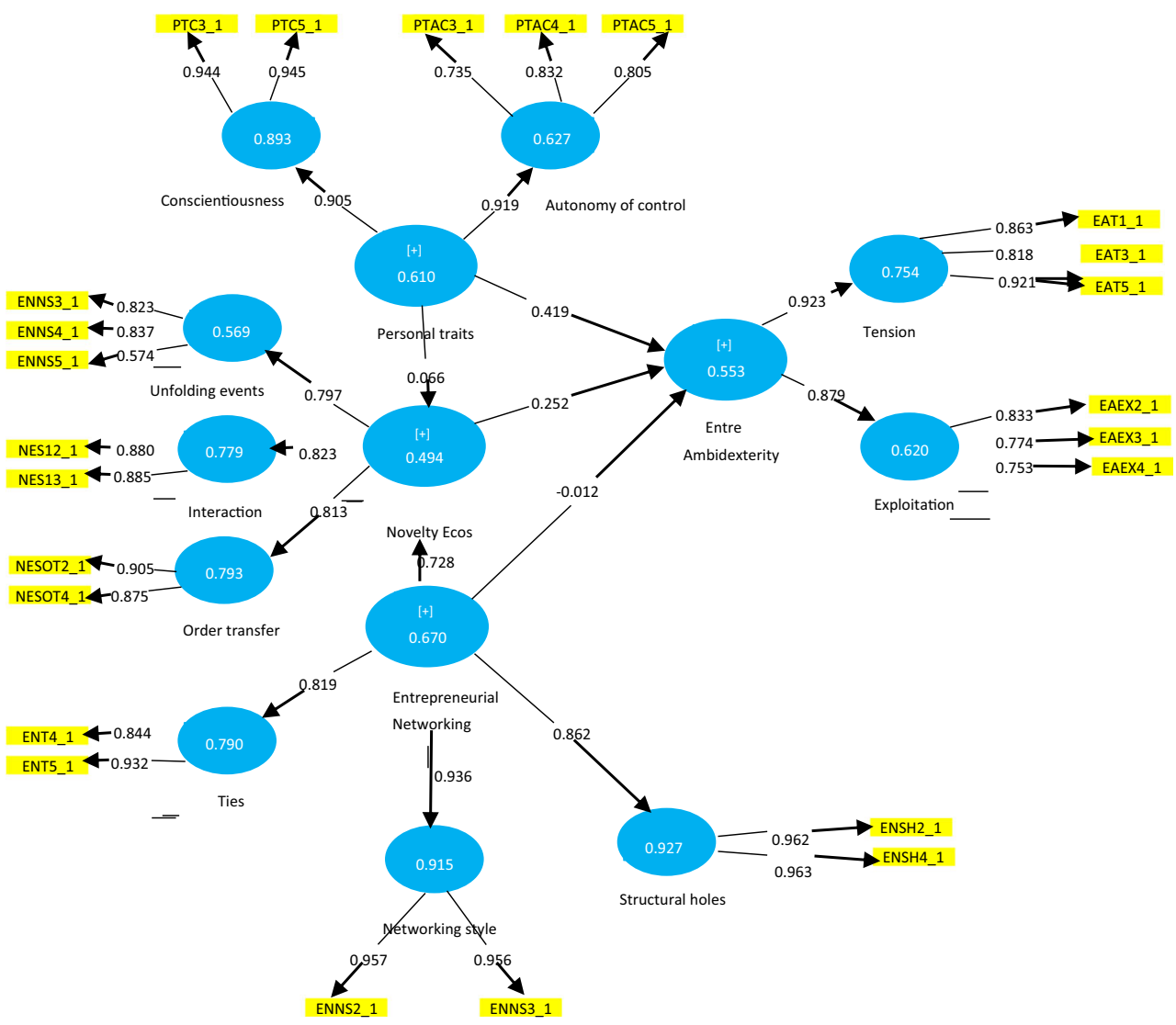

respondents were male, while $40.5 \%$ were female. The percentages by age of respondent were $16.7 \%$ for those of 18-27 years, $33.5 \%$ for those of $28-37$ years, $24.9 \%$ for those of $38-47$ years, $14.1 \%$ for those of $48-57$ and $10.8 \%$ for those of 58 years and above. Regarding the level of education, $21.6 \%$ of the respondents were diploma holders, $18.2 \%$ were degree holders, $16.1 \%$ had done certificates in various courses and $14.6 \%$ had done postgraduate courses in various fields. As for the positions of the respondents, $44.6 \%$ were supervisors, $32.9 \%$ were managers, while $22.9 \%$ were business owners. In terms of working experience, $34 \%$ of the respondents had worked for $6-10$ years, $26.5 \%$ for 11 and above years and $23.2 \%$ for $1-5$ years, while $16.3 \%$ had worked for less than 1 year.

The results show that $32.5 \%$ of the businesses had been running for 6-10 years, $29.6 \%$ for less than $2-5$ years and $21.9 \%$ for over 10 years, while the remaining $15.9 \%$ had been running for 1 year. With regard to the number of employees, $26.3 \%$ of the businesses had five to 14 staff, $22.9 \%$ had 15-24 staff, $18.3 \%$ had 25-34 staff, $13.7 \%$ had 35-44 staff, $10.7 \%$ employed $45-54$ staff, while $8.1 \%$ employed 55 staff and above.

\section{Pearson correlation}

The zero-order correlations for all variables are shown in Table 3. Personality traits were found to be positively related to entrepreneurial ambidexterity $(\mathrm{r}=0.507, \mathrm{p}<0.05)$.
Personality traits were positively associated with novelty ecosystem $(r=0.370, p<0.05)$, whereas novelty ecosystem was positively related to entrepreneurial ambidexterity $(r=0.397$, $\mathrm{p}<0.05$ ). Entrepreneurial networking was also positively associated with novelty ecosystem $(r=0.756, p<0.05)$. These correlations supported $\mathrm{H} 1, \mathrm{H} 2, \mathrm{H} 3$ and $\mathrm{H} 4$ preliminarily. Therefore, personality traits, entrepreneurial networking and novelty ecosystem contribute to entrepreneurial ambidexterity among SMEs.

\section{Hypothesis testing}

PLS-SEM was used to test for the direction and significance of the hypothesised path. Additionally, as recommended by Hair, Sarstedt, Ringle and Gudergan (2018), bootstrapping was done using 5000 sub-samples at $95 \%$ confidence interval to test for the significance of the direct and indirect paths. The results, as set out in Table 4 and Figure 2 below, indicate that personality traits were positively and significantly related to entrepreneurial ambidexterity ( $\beta=0.419, p<0.001$ ). Similarly, $\mathrm{H} 2$ shows that personality traits were positively and significantly associated with novelty ecosystem $(\beta=0.066, \mathrm{p}<0.05)$, whereas in $\mathrm{H} 3$, novelty ecosystem was positively and significantly related to entrepreneurial ambidexterity $(\beta=0.252, p$ $<0.001)$. In $\mathrm{H} 4$, entrepreneurial networking was significantly and positively related to novelty ecosystem $(\beta=0.728, \mathrm{p}<$ 
Table 3 Pearson correlations

\begin{tabular}{|c|c|c|c|c|}
\hline & $\begin{array}{l}\text { Entrepreneurial } \\
\text { ambidexterity }\end{array}$ & $\begin{array}{l}\text { Entrepreneurial } \\
\text { networking }\end{array}$ & $\begin{array}{l}\text { Novelty } \\
\text { ecosystem }\end{array}$ & $\begin{array}{l}\text { Personal } \\
\text { traits }\end{array}$ \\
\hline $\begin{array}{l}\text { Entrepreneurial } \\
\text { ambidexterity }\end{array}$ & 1.000 & & & \\
\hline Entrepreneurial networking & 0.353 & 1.000 & & \\
\hline Novelty ecosystem & 0.397 & 0.756 & 1.000 & \\
\hline Personal traits & 0.507 & 0.418 & 0.370 & 1.000 \\
\hline \multicolumn{5}{|c|}{ **Correlation is significant at the 0.1 level (2-tailed) } \\
\hline \multicolumn{5}{|l|}{ R square } \\
\hline & R square & & R square ad & \\
\hline $\begin{array}{l}\text { Entrepreneurial } \\
\text { ambidexterity }\end{array}$ & 0.308 & & 0.305 & \\
\hline Novelty ecosystem & 0.575 & & 0.573 & \\
\hline \multicolumn{5}{|l|}{ f Square } \\
\hline & Entre ambidexterity & & Novelty eco & \\
\hline \multicolumn{5}{|l|}{$\begin{array}{l}\text { Entrepreneurial } \\
\text { ambidexterity }\end{array}$} \\
\hline Entrepreneurial networking & 0.000 & & 1.029 & \\
\hline Novelty ecosystem & 0.039 & & & \\
\hline Personal traits & 0.207 & & 0.008 & \\
\hline
\end{tabular}

0.001). In H5, entrepreneurial networks were non-significant and negatively related to entrepreneurial ambidexterity $(\beta=-$ $0.012, \mathrm{p}>0.05$ ). The confidence interval bias was at $95 \%$. Still, the quality criteria result summarised in Table 5 below shows that all the hypothesised paths of personality traits, entrepreneurial networking, novelty ecosystem and entrepreneurial ambidexterity have effect sizes of (.34) respectivelyall within the recommended effect sizes of 0.02 (Kock, 2014). Therefore, since both the magnitude of the path coefficient and effect size are high with significance level at $(\mathrm{p}<$ 0.001 ), the confidence that the true effect is proper with the study's final sample size is greater (Hair et al., 2019).

\section{Testing for mediation}

In an attempt to test for the mediation paths (H5, H6) in the model as shown in Table 5 and Figure 2, bootstrapping was done using 5000 sub-samples at $95 \%$. The 5000 sub-samples were considered adequate to ensure stability of the results (Hair Jr et al. , 2017). However, bootstrapping was done twice; first without a mediator and secondly in the presence of a mediator construct. According to Hair et al. (2017), as earlier on suggested by Baron and Kenny (1986), when the direct path is initially not significant, there is no mediation effect, but when the direct path is significant, a mediator variable is introduced, and bootstrapping is done again to test the significance of the indirect path. In other words, if the indirect path is not significant, there is no mediation; if it is, the variance accounted for (VAF) is computed. Notably, when VAF is above $80 \%$, it indicates full mediation; between $20 \%$ and $80 \%$ is partial mediation, while a value less than $20 \%$ indicates no mediation (Hair et al., 2017). Table 5 reveals that all the direct paths were significant; therefore, testing the mediating role of the novelty ecosystem in the relationship between personality traits, entrepreneurial networking and entrepreneurial ambidexterity was meaningful. The results show that the novelty ecosystem plays a partial mediation between personality traits and entrepreneurial ambidexterity $(\beta=0.017$, $\mathrm{p} \leq 0.05$ ). Similarly, the novelty ecosystem partially mediates the relationship between entrepreneurial networking and

Table 4 Direct hypotheses results

\begin{tabular}{|c|c|c|c|c|c|c|}
\hline Direct effect & $\mathrm{B}$ & Std error & $\mathrm{T}$ value & $\mathrm{p}$ values & $2.5 \%$ & $97.5 \%$ \\
\hline Entrepreneurial networking -> entrepreneurial ambidexterity & -0.012 & 0.053 & 0.228 & 0.820 & -0.121 & 0.088 \\
\hline Entrepreneurial networking -> novelty ecosystem & 0.728 & 0.023 & 31.743 & 0.000 & 0.682 & 0.772 \\
\hline Novelty ecosystem $->$ entrepreneurial ambidexterity & 0.252 & 0.047 & 5.305 & 0.000 & 0.158 & 0.344 \\
\hline Personality traits $->$ entrepreneurial ambidexterity & 0.419 & 0.036 & 11.522 & 0.000 & 0.346 & 0.488 \\
\hline Personality traits $->$ novelty ecosystem & 0.066 & 0.029 & 2.241 & 0.025 & 0.010 & 0.124 \\
\hline
\end{tabular}


Table 5 Mediation test results

\begin{tabular}{|c|c|c|c|c|c|c|}
\hline Direct effect & $\beta$ & Std error & $\mathrm{T}$ value & $\mathrm{p}$ values & $2.5 \%$ & $97.5 \%$ \\
\hline Entrepreneurial networking $->$ entrepreneurial ambidexterity & -0.012 & 0.053 & 0.228 & 0.820 & -0.121 & 0.088 \\
\hline Entrepreneurial networking $->$ novelty ecosystem & 0.728 & 0.023 & 31.743 & 0.000 & 0.682 & 0.772 \\
\hline Novelty ecosystem -> entrepreneurial ambidexterity & 0.252 & 0.047 & 5.305 & 0.000 & 0.158 & 0.344 \\
\hline Personal traits $->$ entrepreneurial ambidexterity & 0.419 & 0.036 & 11.522 & 0.000 & 0.346 & 0.488 \\
\hline Personal traits $->$ novelty ecosystem & 0.066 & 0.029 & 2.241 & 0.025 & 0.010 & 0.124 \\
\hline Indirect effects & $\beta$ & Std error & $\mathrm{T}$ value & $\mathrm{p}$ values & $2.5 \%$ & $97.5 \%$ \\
\hline Entrepreneurial networking $->$ novelty ecosystem $->$ entrepreneurial ambidexterity & 0.183 & 0.036 & 5.027 & 0.000 & 0.115 & 0.259 \\
\hline Personal traits $->$ novelty ecosystem $->$ entrepreneurial ambidexterity & 0.017 & 0.007 & 2.307 & 0.021 & 0.004 & 0.032 \\
\hline Total effect & $\beta$ & Std error & $\mathrm{T}$ value & $\mathrm{p}$ values & $2.5 \%$ & $97.5 \%$ \\
\hline Entrepreneurial networking -> entrepreneurial ambidexterity & 0.171 & 0.041 & 4.205 & 0.000 & 0.092 & 0.251 \\
\hline Entrepreneurial networking $->$ novelty ecosystem & 0.728 & 0.023 & 31.743 & 0.000 & 0.682 & 0.772 \\
\hline Novelty ecosystem $->$ entrepreneurial ambidexterity & 0.252 & 0.047 & 5.305 & 0.000 & 0.158 & 0.344 \\
\hline Personal traits $->$ entrepreneurial ambidexterity & 0.435 & 0.036 & 12.121 & 0.000 & 0.363 & 0.503 \\
\hline Personal traits -> novelty ecosystem & 0.066 & 0.029 & 2.241 & 0.025 & 0.010 & 0.124 \\
\hline
\end{tabular}

entrepreneurial ambidexterity $(\beta=0.183, p \leq 0.001)$. This is in line with the suggestions of Hair et al. (2017) that direct and indirect paths being significant indicates that personality traits and entrepreneurial networking directly relate with entrepreneurial ambidexterity but go through the novelty ecosystem.

\section{Assessment of HOC measurement model for entrepreneurial ambidexterity}

\section{Discussion}

\section{H1: Personality traits and entrepreneurial ambidexterity}

Personality traits comprising consciousness and autonomy are associated with entrepreneurial ambidexterity. This means that an entrepreneur who is dependable, hardworking and persistent is likely to identify business opportunities, harmonise competing ideas for resources and evaluate the business options to take advantage of available opportunities. This view is comprehensible because in business one has to be reliable, has to work hard and should be able to persevere through difficult times. Business owners/managers of the SMEs studied exhibited the consciousness personality trait. This finding is supported by previous studies, which confirmed that consciousness has an association with entrepreneurial ambidexterity (Kerr et al., 2018; Leutner et al., 2014).

Similarly, an entrepreneur who is independent and has the freedom to set his/her own goals in a defined environment is likely to successfully explore and exploit opportunities. In essence, an entrepreneur who is autonomous has the freedom to evaluate and allocate resources to viable opportunities to achieve personal and business objectives. Previous studies show that autonomy of control influences the behaviour to explore and exploit an opportunity (Ozaralli \& Rivenburgh, 2016).

The nature of macro-personality traits cannot easily predict the situation-specific behaviours of entrepreneurs in understanding the explicit mechanisms through which personality impacts entrepreneurial attitudes and actions (Rauch, 2014). Levine and Rubinstein (2017) add that typical personality traits of individuals will vary greatly by form of entrepreneurial activity. In this study, traits like consciousness and autonomy of control explain the major traits that influence opportunity exploration and exploitation among SMEs in Uganda. This renders support to complexity system leadership theory because the personality traits of the entrepreneur will influence the entrepreneurial ambidexterity.

\section{H2: Personality traits and novelty ecosystem}

Personality traits influence the creation of novelty ecosystems. SME owners/managers conscientiously create environments which enable their interactions where they think they are going to benefit and minimise conflicts. They benefit by joining different networks to access scarce resources, creating new linkages for benchmarking, which are useful in supporting innovations in terms of coming up with new production systems, products and services. The results suggest that SME owners/managers in Uganda are very conscious about which network to belong in which will not negate their objectives. Consciousness of an entrepreneur combined with other factors, such as culture, institutions and local networks, all play a role in creating a novelty ecosystem for a business to thrive in a competitive environment (Brown \& Mason, 2017). 
Fig. 2 PLS-SEM for entrepreneurial ambidexterity

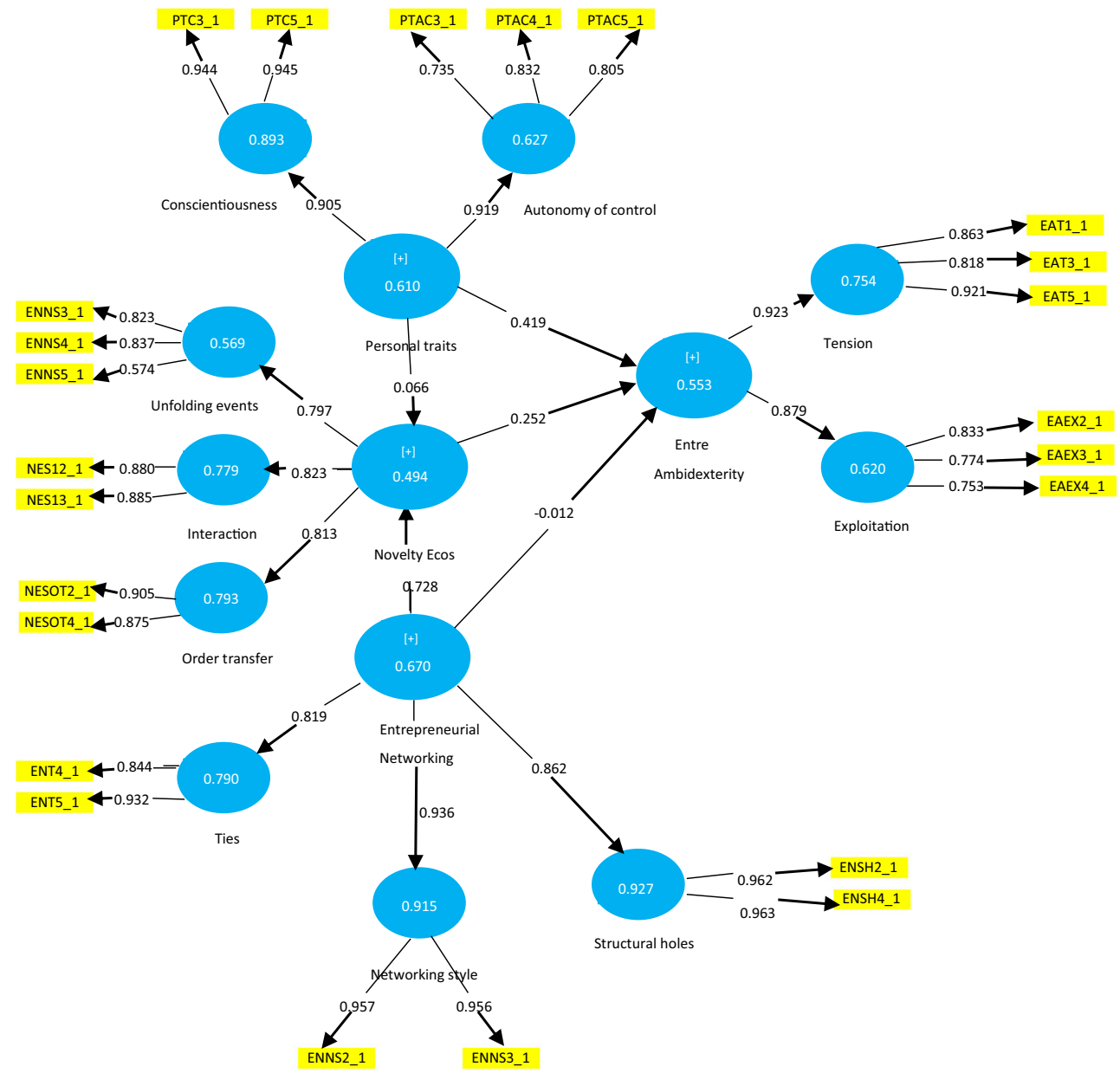

Relatedly, the results show that owner-managers of SMEs have autonomy of control to decide which network to join or to leave. This is because owner-managers join the networks which they deem to suit their interests. In the context of Uganda, owner-managers invest efforts to create an environment that is conducive for networks to flourish by allowing employee interactions both internally and externally for learning and new idea development. Autonomy of control is related to goaldirected behaviour which requires predefined goals, coupled with existing knowledge, competencies and previous experience, in order to exploit it for goal attainment (Lindhult \& Hazy, 2016).

Frese and Gielnik (2014) found that entrepreneurs and managers are similar in dependability, but entrepreneurs score significantly higher than managers in the achievement facet. People cannot be separated from the environment which they inhabit, and the well-being of any individual depends largely on the extent to which the environment can provide opportunities to satisfy their need for autonomy. Autonomy and support available to an entrepreneur enable them to work and align activities with the other person's interests and preferences. Autonomy helps an entrepreneur to create an enabling environment where employees express alternative views as well as learn from one another through interactions and feedback (Legault, 2016).
Hurst and Pugsley (2011) found that the vast majority of small businesses do not intend to innovate or expand their operations, but are instead content to remain at their current size and scope. They further assert that non-pecuniary motivations, including the desire for autonomy and self-fulfilment, are now accepted to be an integral part of many decisions to create new businesses, and thus measures of venture returns or growth may misgauge the true returns that these entrepreneurs experience. When people have autonomy and enthusiasm, they also succeed better, at least in creating novelty ecosystems through employee interactions, feedback and experiments. Personality traits like conscientiousness and autonomy of control provide a versatile range of cognitive frameworks and ideas for associational thinking, questioning, observing and experiencing, which are vital in creating novelty ecosystems for SMEs.

\section{H3: Novelty ecosystem and entrepreneurial ambidexterity}

Environments where SME business owners/managers apply tolerance of failure and encourage employees to achieve desired goals with a degree of freedom are likely to promote entrepreneurial ambidexterity. Whenever SME owners/ 
managers put in place designs and systems to monitor the emerging multi-level events as they unfold, it is more likely that the employees will strive to explore and exploit opportunities in such dynamic environment. The owner-manager not only nurtures employees' creativity in addressing the prevailing challenges but also generates more spontaneous ideas, comes up with new venture creations and, hence, experiences a history of opportunity exploration, tension and exploitation. A novelty ecosystem focuses on interactions as well as employee ties developed through trust and exchanges to provide and access diverse knowledge through ecosystems, eco-subsystems and their environments (Yeganegi et al., 2019). These ecosystems are made up of a vast set of complex interchanges and non-linear changes or effects connected to one another's adaptive and interactive systems (Sarango-Lalangui, 2018).

Mayanja et al. (2019) posit that an SME owner-manager should promote new idea generation processes by allowing complex interchanges and non-linear interactions among employees. A novelty ecosystem allows employees to operate through thinking of the business environment in terms of an ecosystem in order to initiate change, whether it is incremental, radical or revolutionary, to explore and exploit opportunities.

\section{H4: Entrepreneurial networks and novelty ecosystems}

Entrepreneurial networks were not associated with novelty ecosystems. This means that resources from social networks may not necessarily influence the emergence dynamism of creating a novelty ecosystem among SMEs. Those SME owners/managers who may identify useful resources for opportunity exploitation may end up not applying emergence dynamism and failure to tolerate or encourage employees to achieve the desired goals because of the fear of not being able to control the novelty ecosystems. Innovation occurs most effectively when there is an exchange of knowledge among employees to improve the existing systems and processes in order to utilise the entrepreneurial networks for business competitiveness (Mayanja et al., 2019). The importance of diversity of thought among employees may not necessarily help in developing new ideas and relationships that create dynamic networking for business support because the business owner wants to control all innovations (Liu, 2018).

Acton et al. (2019) observed that emergence dynamism may not necessarily enable a web of interaction within the organisation that produce positive and negative feedback for the kind of network needed for participation. Complexity systems leadership theory explains the importance of entrepreneur leadership skills in managing entrepreneurial networks and novelty ecosystem for competitiveness (Hazy \& UhlBien, 2015).

\section{H5: Entrepreneurial networks and entrepreneurial ambidexterity}

The results reveal a non-significant negative relationship between entrepreneurial networks and entrepreneurial ambidexterity. This means that business owner-managers may be part of an entrepreneurial network but without the necessary social competencies to get the needed resources from the network actors. The network actors may end up not supporting all network members to achieve their objectives because they may be competing against their personal or business objectives. There are entrepreneurial networks that may not have resources fit for all its members to access the necessary support. Venkatesh et al. (2017) posit that established and newly formed entrepreneurial networks can be instrumental in exploring opportunities if the entrepreneur has the skills of leveraging social and business networks. The entrepreneurial networks may potentially not lead to collaborative cooperation and form part of an entrepreneur's broader business network to facilitate the exploitation of opportunities to successfully enter into foreign markets without understanding the network dynamics in a competitive environment.

The results contradict Castano-Martinez et al.'s (2019) conclusion that entrepreneurial networks have a positive impact on entrepreneurial exploration and exploitation. However, in the current dynamic environment, some entrepreneurial networks may not support the exploration and exploitation of the opportunities because they may be weak or have competing and divergent interests.

\section{H6: A novelty ecosystem mediates the relationship between personality traits and entrepreneurial ambidexterity}

Novelty ecosystems partially mediate the relationship between personality traits and entrepreneurial ambidexterity among SMEs. This means that whenever employees interact and share new conceptions based on the business mindset, they are likely to explore and exploit opportunities. The improved behaviours in work methods developed by business owners/managers and quickly applied in the business set-up are likely to enable business employees to develop the zeal of learning how to deal with prevailing new challenges creatively. The antecedents of spontaneous generation of ideas alongside opportunity exploration create tension that needs a novelty ecosystem to exploit old and new opportunities. Complexity leadership theory has it that when agents interact, they may experience tension in the form of pressures and challenges to their personal knowledge base (Lindhult \& Hazy, 2016). However, the study findings posit that such tension is significantly associated with opportunity tension and employee innovativeness only through encouragements received from the business owner-manager, tolerance of failure 
measures exercised by management, the degree of freedom provided to achieve the desired goals and the availability of systems designed to monitor the emerging events (novelty ecosystem-mediation). In other words, a novelty ecosystem acts as a conduit through which personality traits could intensify opportunity exploration, tension and exploitation among SME employees (Lee \& Lee, 2016).

\section{H7: A novelty ecosystem mediates the relationship between entrepreneurial networks and entrepreneurial ambidexterity}

A novelty ecosystem partially mediates the relationship between entrepreneurial networks and entrepreneurial ambidexterity among SMEs. Entrepreneurial networks provide various benefits to the entrepreneur, such as supporting innovation, the perception and recognition of opportunities, access to the exchange of resources, provision of relevant information and incremental opportunity exploration and exploitation. Entrepreneurial networks facilitate the necessary and sufficient conditions for transferring information and resources that favour the creation of a novelty ecosystem that supports entrepreneurial ambidexterity (Castaño-Martínez et al., 2019). Moreover, these entrepreneurial networks develop synergies that give rise to creative ideas and combinations through novelty ecosystems. The success or failure of entrepreneurial ambidexterity is through the introduction of novelty ecosystems which often depend on internal and external changes in their environment and the interaction of employees ( $\mathrm{O}^{\prime}$ Connor et al., 2018).

\section{Conclusion and implications}

Personality traits like conscientiousness, explained by dependability, hard work and perseverance, are associated with entrepreneurial ambidexterity among SMEs. In addition, personality traits influence the creation of novelty ecosystems. Entrepreneurial networks were not associated with novelty ecosystems. This means that resources from social networks may not necessarily influence the emergent dynamism of creating a novelty ecosystem among SMEs. A novelty ecosystem partially mediates the relationship between personality traits, entrepreneurial networking and entrepreneurial ambidexterity. A novelty ecosystem is a conduit through which personality traits and entrepreneurial networks influence entrepreneurial ambidexterity among SMEs in Uganda. This mediation effect, therefore, constitutes a fundamental avenue through which employees' decision to explore, manage tension and exploit opportunities can be enhanced.

For purposes of policy, the government should build incubation centres, support business counsellors to mentor entrepreneurs based on their personality traits and support novelty ecosystems based on research about global trends.

The National Planning Authority (NPA) advocates that for SMEs to grow, they need to access tangible and intangible resources. The study findings indicate that for SMEs to explore and exploit opportunities in a competitive environment, networks are crucial for resource mobilisation. In view of this, we suggest that the government should support SME networking by establishing a government agency as an information business hub to coordinate local and international information about entrepreneurial opportunities of SMEs (National Planning Authority, 2019).

SME owners/managers should support employees to develop the zeal of learning how to deal with prevailing new challenges creatively and to stimulate spontaneous new idea generation to explore, manage tension and exploit opportunities. SME owners/managers should provide employees with the freedom to try their own ways of doing things and encourage employees to make use of their ability and their own judgement even when they deviate from the norms in a complex environment.

SMEs need policies that enhance employee interaction interfaces, consider the need to redesign novelty ecosystems by promoting employee interactions and encourage feedback so as to learn from their experiences. Social implications, higher degrees of employee interaction, information exchange and innovation are likely to yield favourable entrepreneurial ambidexterity.

Entrepreneurs should seek a balance between exploration and exploitation activities in their business operations. Entrepreneurs with personality traits of autonomy to control are more aligned to exploration activities, while those with conscientiousness are closely linked with exploitation activities. We suggest that it is important for SME managers to serve as role models of ambidextrous behaviour in order to foster non-managerial employee ambidexterity.

\section{Limitations and extensions}

Despite the contributions of this study, its findings should not be interpreted without recognising its limitations. For example, the study used a cross-sectional survey research design which investigates the variables in a snapshot, but variables like personality traits, entrepreneurial networks, novelty ecosystem and entrepreneurial ambidexterity need to be studied over time. The researchers targeted many SMEs to guide against the response bias associated with such a design (Bryman \& Bell, 2011). Also, the fact that the sample population used in this study was restricted to SMEs in Kampala district because of its unique placement as the business hub of Uganda hinders the possibility of extrapolating its results. Future research may extend this study to a broader population 
of SMEs in the agriculture and transport sectors to detect potential differential effects. This can be based on the fact that the characteristics of the industry determine the direct or indirect effect of personality traits, entrepreneurial networks, novelty ecosystems and entrepreneurial ambidexterity.

Abbreviations SMEs, small and medium enterprises; CSLT, complexity systems leadership theory; MCAR, missing completely at random; CVI, current validity index; SD, standard deviation; SPSS, Statistical Package for the Social Sciences; CVS, Concurrent Versions System command; SEM, structural equation model; PLS, partial least squares; HOC model, higher-order constructs

Acknowledgements The authors are grateful to the Almighty God.

Availability of data and materials The data set generated and analysed during the study, it is publicly available. However, the dataset is available from the corresponding author on reasonable request.

Author contribution SM guided the theoretical debate and logical flow of the study. JVT collected the data and conceptualised the study. JMN analysed and interpreted the data. MO guided on the global debates of entrepreneurial ambidexterity. HM analysed the data and contributed to the methodology content. FM proofread the work. All authors were involved in the preparation of the manuscript. The authors read and approved the final manuscript.

\section{Declarations}

Competing interests The authors declare no competing interests.

Open Access This article is licensed under a Creative Commons Attribution 4.0 International License, which permits use, sharing, adaptation, distribution and reproduction in any medium or format, as long as you give appropriate credit to the original author(s) and the source, provide a link to the Creative Commons licence, and indicate if changes were made. The images or other third party material in this article are included in the article's Creative Commons licence, unless indicated otherwise in a credit line to the material. If material is not included in the article's Creative Commons licence and your intended use is not permitted by statutory regulation or exceeds the permitted use, you will need to obtain permission directly from the copyright holder. To view a copy of this licence, visit http://creativecommons.org/licenses/by/4.0/.

\section{References}

Andriopoulos, C., \& Lewis, M. W. (2009). Exploitation-exploration tensions and organizational ambidexterity: Managing paradoxes of innovation. Organization Science, 20(4), 696-717.

Aschenbrücker, K., \& Kretschmer, T. (2018). Balanced control as an enabler of organizational ambidexterity. Organization Design (Advances in Strategic Management, Vol. 40).

Baron, R. A., \& Ensley, M. D. (2006). Opportunity recognition as the detection of meaningful patterns: Evidence from comparisons of novice and experienced entrepreneurs. Management Science, 52(9), 1331-1344.

Baron, R. M., \& Kenny, D. A. (1986). The moderator-mediator variable distinction in social psychological research: Conceptual, strategic, and statistical considerations. Journal of Personality and Social Psychology, 51(6), 1173-1182.

Bhatt, P., \& Altinay, L. (2013). How social capital is leveraged in social innovations under resource constraints? Management Decision, 51(9), 1772-1792.

Brown, R., \& Mason, C. (2017). Looking inside the spiky bits: A critical review and conceptualisation of entrepreneurial ecosystems. Small Business Economics, 49(1), 11-30.

Carayannis, E. G., \& Rakhmatullin, R. (2014). The quadruple/quintuple innovation helixes and smart specialisation strategies for sustainable and inclusive growth in Europe and beyond. Journal of the Knowledge Economy, 5(2), 212-239.

Castaño-Martínez, M. S., Galindo-Martín, M. Á., Méndez-Picazo, M. T., \& Palacios-Marqués, D. (2019). Relationship between ambidexterity and entrepreneurial intensity. Economic Research-Ekonomska istraživanja, $1-17$.

Chin, W. W., \& Dibbern, J. (2010). An introduction to a permutation based procedure for multi-group PLS analysis: Results of tests of differences on simulated data and a cross cultural analysis of the sourcing of information system services between Germany and the USA. In Handbook of partial least squares (pp. 171-193). Berlin, Heidelberg: Springer.

Christensen, A. P., Kenett, Y. N., Cotter, K. N., Beaty, R. E., \& Silvia, P. J. (2018). Remotely close associations: Openness to experience and semantic memory structure. European Journal of Personality, 32(4), 480-492.

Costanza, R., De Groot, R., Braat, L., Kubiszewski, I., Fioramonti, L., Sutton, P., \& Grasso, M. (2017). Twenty years of ecosystem services: How far have we come and how far do we still need to go? Ecosystem Services, 28, 1-16.

Czernek-Marszałek, K. (2020). Social embeddedness and its benefits for cooperation in a tourism destination. Journal of Destination Marketing \& Management, 15, 100401.

Davidsson, P., \& Honig, B. (2003). The role of social and human capital among nascent entrepreneurs. Journal of Business Venturing, 18(3), 301-331.

Faul, F., Erdfelder, E., Lang, A. G., \& Buchner, A. (2007). G* Power 3: A flexible statistical power analysis program for the social, behavioral, and biomedical sciences. Behavior Research Methods, 39(2), 175191.

Field, A. (2009). Discovering statistics using SPSS (and sex and drugs and rock " $n$ " roll). London: Sage Publications.

Foreby, F., Tammisto, M., \& Åberg, R. (2016). Exploration and exploitation activities in start-ups: The role of network participation. Lund: Lund University Press.

Fornell, C., \& Larcker, D. F. (1981). Evaluating structural equation models with unobservable variables and measurement error. Journal of Marketing Research, 18(1), 39-50.

Frese, M., \& Gielnik, M. M. (2014). The psychology of entrepreneurship. Annu. Rev. Organ. Psychol. Organ. Behav., 1(1), 413-438.

Gibson, C. B., \& Birkinshaw, J. (2004). The antecedents, consequences, and mediating role of organizational ambidexterity. Academy of Management Journal, 47(2), 209-226.

Goldstein, J., Hazy, J., \& Lichtenstein, B. B. (2010). Complexity and the nexus of leadership: everaging nonlinear science to create ecologies of innovation. New York: Palgrave Macmillan.

Hair Jr., J. F., Sarstedt, M., Ringle, C. M., \& Gudergan, S. P. (2017). Advanced issues in partial least squares structural equation modeling. Sage Publications.

Hair, J. F., Black, W. C., Babin, B. J., \& Anderson, R. E. (2010). Multivariate data analysis. Pearson Prentice Hall.

Hair, J. F., Risher, J. J., Sarstedt, M., \& Ringle, C. M. (2019). When to use and how to report the results of PLS-SEM. European Business Review., 31, 2-24.

Harrison, D. A., McLaughlin, M. E., \& Coalter, T. M. (1996). Context, cognition, and common method ariance: Psychometric and verbal 
protocol evidence. Organizational Behavior and Human Decision Processes, 68(3), 246-261.

Hayek, F. A. (1945). The use of knowledge in society. The American Economic Review, 35(4), 519-530.

Haynie, J. M., Shepherd, D. A., \& McMullen, J. S. (2009). An opportunity for me? The role of resources in opportunity evaluation decisions. Journal of Management Studies, 46(3), 337-361.

Hazy, J. K., \& Uhl-Bien, M. (2015). Towards operationalizing complexity leadership: How generative, administrative and communitybuilding leadership practices enact organizational outcomes. Leadership, 11(1), 79-104.

Henseler, J., Ringle, C. M., \& Sarstedt, M. (2016). Testing measurement invariance of composites using partial least squares. International Marketing Review, 33(3), 405-431.

Hoang, H., \& Yi, A. (2015). Network-based research in entrepreneurship: A decade in review. Foundations and Trends ${ }^{\circledR}$ in Entrepreneurship, 11(1), 1-54.

John, O. P., \& Robins, R. W. (1994). Traits and types, dynamics and development: No doors should be closed in the study of personality. Psychological Inquiry, 5(2), 137-142.

Junni, P., Sarala, R. M., Tarba, S. Y., Liu, Y., \& Cooper, C. L. (2015). Guest editors' introduction: The role of human resources and organizational factors in ambidexterity. Human Resource Management, 54(S1), s1-s28.

Karabulut, A. T. (2016). Personality traits on entrepreneurial intention. Procedia-Social and Behavioral Sciences, 229, 12-21.

Keller, T., \& Weibler, J. (2014). Behind managers' ambidexterity Studying personality traits, leadership, and environmental conditions associated with exploration and exploitation. Schmalenbach Business Review, 66(3), 309-333.

Kerr, S. P., Kerr, W. R., \& Xu, T. (2018). Personality traits of entrepreneurs: A review of recent literature. Foundations and Trends ${ }^{\circledR}$ in Entrepreneurship, 14(3), 279-356.

Kibirango, M. M., Munene, J. C., Balunywa, W. J., \& Obbo, J. K. (2017). Mediation effect of novelty-ecosystems on intrapreneurial behaviour process within an organisational dynamic environment among Kenyan universities: A complexity approach. Journal of Organizational Change Management, 30(6), 941-961.

Kock, N. (2014). Advanced mediating effects tests, multi-group analyses, and measurement model assessments in PLS-based SEM. International Journal of e-Collaboration (IJeC), 10(1), 1-13.

Krejcie, R. V., \& Morgan, D. W. (1970). Determining sample size for research activities. Educational and Psychological Measurement, 30(3), 607-610.

Lamoureux, E. L., Pallant, J. F., Pesudovs, K., Hassell, J. B., \& Keeffe, J. E. (2006). The impact of vision impairment questionnaire: An evaluation of its measurement properties using Rasch analysis. Investigative Ophthalmology \& Visual Science, 47(11), 4732-4741.

Lee, Y.-J., \& Lee, J.-H. (2016). Knowledge workers' ambidexterity: Conceptual separation of competencies and behavioural dispositions. Asian Journal of Technology Innovation, 24(1), 22-40.

Legault, L. (2016). Intrinsic and extrinsic motivation. In V. Zeigler-Hill \& T. Shackelford (Eds.), Encyclopedia of Personality and Individual Differences. New York: Springer. Retrieved from. https://doi.org/ 10.1007/978-3-319-28099-8 1139-1.

Leutner, F., Ahmetoglu, G., Akhtar, R., \& Chamorro-Premuzic, T. (2014). The relationship between the entrepreneurial personality and the Big Five personality traits. Personality and Individual Differences, 63, 58-63.

Levine, R., \& Rubinstein, Y. (2017). Smart and illicit: Who becomes an entrepreneur and do they earn more? The Quarterly Journal of Economics, 132(2), 963-1018.

Lindhult, E., \& Hazy, J. K. (2016). Complexity approach to joint value discovery in service innovation management. International Journal of Complexity in Leadership and Management, 3(1-2), 115-138. https://doi.org/10.1504/IJCLM.2016.075046.
Luger, J., Raisch, S., \& Schimmer, M. (2018). Dynamic balancing of exploration and exploitation: The contingent benefits of ambidexterity. Organization Science, 29(3), 449-470.

Mason, C., \& Brown, R. (2014). Entrepreneurial ecosystems and growth oriented entrepreneurship. Final Report to OECD, Paris, 30(1), 77102.

Mayanja, S., Ntayi, J. M., Munene, J. C., Kagaari, J. R. K., \& Waswa, B. (2019). Ecologies of innovation among small and medium enterprises in Uganda as a mediator of entrepreneurial networking and opportunity exploitation. Cogent Business \& Management, 6(1), 1641256. Retrieved from. https://doi.org/10.1080/23311975.2019. 1641256.

McMillan, E. (2008). Complexity, management and the dynamics of change: Challenges for practice. Routledge.

Mitchell, R., Busenitz, L., Lant, T., McDougall, P., Morse, E., \& Smith, J. (2002). Toward a theory of entrepreneurial cognition: Rethinking the people side of entrepreneurship. Entrepreneurship Theory and Practice, 27(2), 93-105.

Mom, T. J., Van Den Bosch, F. A., \& Volberda, H. W. (2009). Understanding variation in managers' ambidexterity: Investigating direct and interaction effects of formal structural and personal coordination mechanisms. Organization Science, 20(4), 812-828.

Moraes, G. H. S. M. D., Iizuka, E. S., \& Pedro, M. (2018). Effects of entrepreneurial characteristics and university environment on entrepreneurial intention. Revista de Administração Contemporânea, 22(2), 226-248.

Mullins, J. W., \& Forlani, D. (2005). Missing the boat or sinking the boat: A study of new venture decision making. Journal of Business Venturing, 20(1), 47-69.

O'Connor, A., Stam, E., Sussan, F., \& Audretsch, D. B. (2018). Entrepreneurial ecosystems. Place-based transformations and transitions. NY: Springer.

Ozaralli, N., \& Rivenburgh, N. K. (2016). Entrepreneurial intention: Antecedents to entrepreneurial behavior in the USA and Turkey. Journal of Global Entrepreneurship Research, 6(1), 3.

Podsakoff, P. M., MacKenzie, S. B., Lee, J. Y., \& Podsakoff, N. P. (2003). Common method biases in behavioral research: A critical review of the literature and recommended remedies. Journal of Applied Psychology, 88(5), 879-903.

Podsakoff, P. M., MacKenzie, S. B., \& Podsakoff, N. P. (2012). Sources of method bias in social science research and recommendations on how to control it. Annual Review of Psychology, 63, 539-569.

Rauch A (2014) Predictions of entrepreneurial behavior: A personality approach. In Handbook of research on small business and entrepreneurship. Edward Elgar Publishing.

Seidel, M. D. L., \& Greve, H. R. (2017). Emergence: How novelty, growth, and formation shape organizations and their ecosystems emergence. Research in the Sociology of Organizations, 50, 1-27. https://doi.org/10.1108/S0733-558X20170000050020.

Shane, S., \& Venkataraman, S. (2000). The promise of entrepreneurship as a field of research. Academy of Management Review, 25(1), 217226.

Shane, S., \& Venkataraman, S. (2003). Guest editors' introduction to the special issue on technology entrepreneurship. Research Policy, 32(2), 181-184.

Sidhu, J. S., Volberda, H. W., \& Commandeur, H. R. (2004). Exploring exploration orientation and its determinants: Some empirical evidence. Journal of Management Studies, 41(6), 913-932.

Strobl, A., \& Peters, M. (2013). Entrepreneurial reputation in destination networks. Annals of Tourism Research, 40, 59-82.

Sullivan, D. M., \& Ford, C. M. (2014). How entrepreneurs use networks to address changing resource requirements during early venture development. Entrepreneurship Theory and Practice, 38(3), 551-574.

Surie, G., \& Hazy, J. K. (2006). Generative leadership: Nurturing innovation in complex systems. E:CO Issue, 8(4 2006), 13-26. 
Tourangeau, R., Rips, L. J., \& Rasinski, K. (2000). The psychology of survey response. Cambridge: Cambridge University Press.

Turyahikayo, E. (2015). Challenges faced by small and medium enterprises in raising finance in Uganda. International Journal of Public Administration and Management Research, 3(2), 21-33.

Uganda Investment Authority (UIA), (2016)

Venkatesh, V., Shaw, J. D., Sykes, T. A., Wamba, S. F., \& Macharia, M. (2017). Networks, technology, and entrepreneurship: A field quasiexperiment among women in rural India. Academy of Management Journal, 60(5), 1709-1740.

Vissa, B. (2012). Agency in action: Entrepreneurs' networking style and initiation of economic exchange. Organization Science, 23(2), 492 510.

Vodă, A. I., \& Florea, N. (2019). Impact of personality traits and entrepreneurship education on entrepreneurial intentions of business and engineering students. Sustainability, 11(4), 1192.

Volery, T., Mueller, S., \& von Siemens, B. (2015). Entrepreneur ambidexterity: A study of entrepreneur behaviours and competencies in growth-oriented small and medium-sized enterprises. International Small Business Journal, 33(2), 109-129.

Voss, G. B., Sirdeshmukh, D., \& Voss, Z. G. (2008). The effects of slack resources and environmental threat on product exploration and exploitation. Academy of Management Journal, 51(1), 147-164.

Wang, C. L., \& Chugh, H. (2014). Entrepreneurial learning: Past research and future challenges. International Journal of Management Reviews, 1(16), 24-61.

Williams, M. (2019). Scales of measurement and statistical analyses. Retrieved from https://doi.org/10.31234/osf.io/c5278

Yap, C.S., Ahmad, R., Hashim, N.A., \& Jalaludin, F.W. (2017). Personality traits, entrepreneur's ambidexterity, and knowledge brokerage: Evidence from technology firms. In KMIS (pp. 61-69).

Yeganegi, S., Laplume, A. O., Dass, P., \& Greidanus, N. S. (2019). Individual-level ambidexterity and entrepreneurial entry. Journal of Small Business Management, 57(4), 1444-1463. 